\title{
Trade versus aid: donor generosity in an era of globalization
}

\author{
Erik Lundsgaarde $\cdot$ Christian Breunig · Aseem Prakash
}

Published online: 5 July 2007

(C) Springer Science+Business Media B.V. 2007

\begin{abstract}
Why do foreign aid budgets vary across countries and over time? Existing research indicates that the same set of factors shapes commitments toward both domestic and international redistribution. While scholars have acknowledged international normative influences on aid allocations, research on levels of donor generosity has not examined how international trade influences aid budgets. This paper examines whether imports from developing countries have a 'displacement effect' on aid commitments. Employing a panel of nineteen OECD donor countries, we analyze aid budgets from 1980 to 2000. We find that increased imports from developing countries to donor countries are associated with aid reductions. These results persist after controlling for international and domestic variables identified in previous research, and under other estimation techniques and model specifications.
\end{abstract}

Keywords Foreign aid · Donor generosity · Trade

\section{Introduction}

[I]n Latin America and in the Caribbean, a new generation of leaders, with the support of their citizens, has turned increasingly to market forces as they've pursued economic reforms designed to encourage growth. And we've welcomed these

E. Lundsgaarde $(\bowtie) \cdot$ A. Prakash

Department of Political Science, University of Washington, Box 353530, Seattle

WA 98195-3530, USA

e-mail: elgaarde@u.washington.edu

C. Breunig

Department of Political Science, University of Toronto, Ontario, Canada

e-mail: cbreunig@u.washington.edu

A. Prakash

e-mail: aseem@u.washington.edu 
developments, and that's why, in June, we announced the "Enterprise for the Americas Act," a major new initiative, to help forge a genuine partnership of freemarket reform that will sustain both growth and political stability in Latin America and the Caribbean. I consider this one of the most important initiatives of my administration, and it opens a bold new chapter in hemispheric relations, one based on trade, not aid.

— US President George Bush, September 14, 1990 (Federal News Service 1990).

Foreign aid is a key instrument that developed countries can employ to alleviate resource scarcity, reduce inequalities, and support policy reforms in the developing world (Collier and Dollar 2004). The size of foreign aid budgets varies considerably across donor countries and over time. For instance, in 2000, Denmark's foreign aid commitments represented $1.06 \%$ of its gross national product (GNP) while U.S. aid allocations amounted to only $0.1 \%$ of its GNP. France has halved its foreign aid outlays in the last two decades: from $0.64 \%$ of its GNP in 1980 to $0.32 \%$ of its GNP in 2000. What explains these variations in budgetary commitments to foreign aid?

Prior research suggests that countries with higher levels of domestic social spending, stronger leftist political parties, and more popular support for international redistribution have larger aid budgets (Lumsdaine 1993; Noël and Thérien 1995, 2002; Thérien and Noël 2000). Scholars also acknowledge the influence of international norms on aid policy. Although this research has highlighted several plausible explanations for variations in aid provision, the literature on the determinants of donor generosity leaves a core theoretical issue unresolved. Aid is one of several instruments that donor countries can employ to facilitate economic development in the developing world. As a consequence, aid giving can be influenced by donor attitudes toward alternative policy instruments aimed at achieving similar goals. Along with aid, donor countries can promote economic development by providing market access for developing country exports. The volume of imports from developing countries to donor countries in the Organization for Economic Cooperation and Development (OECD) has increased substantially over the past two decades, rising from around 188 billion dollars in 1980 to nearly 1.3 trillion dollars in 2000 (UNCTAD 2004). For individual donor governments, increased trade with the developing world may create opportunities to pare down aid budgets and divert budgetary resources to more popular domestic programs while demonstrating a continued commitment to international development goals because policy makers can justify aid reductions by pointing towards increasing imports from developing countries as a sign that development strategies that do not rely on aid are working. Our analysis seeks to determine whether there is evidence that this logic of trade displacing foreign aid has influenced patterns of donor aid commitments.

This study examining the relationship between trade with the developing world and donor aid commitments is novel because we suggest that donor generosity should be viewed as a question of instrument choice and budgetary politics. ${ }^{1}$ We investigate whether rising imports from developing countries have created opportunities for politicians to put the 'trade not aid' perspective often associated with the 'Washington Consensus' into

\footnotetext{
1 The literature on budgetary politics is well-established in political science. Key works include Wildavsky (1992), and Jones et al. (1998). Unlike these works, this paper has a cross-country focus. This study also differs from Jones et al. (1998) insofar as we are not studying whether (and why) in a given country there were periods of stability and change regarding instrument choice.
} 
practice and contributed to reductions in aid budgets. ${ }^{2}$ Using a panel of 19 OECD countries, we examine aid budgets from 1980 to 2000. Our results indicate that increased imports from developing countries are associated with reduced aid. In contrast to previous research, we do not find a statistically significant relationship between domestic welfare expenditures and foreign aid budgets. Nor do we find that international normative influences are driving aid budgets. These results persist even after controlling for a slate of international and domestic variables and after employing different estimation techniques and model specifications.

\section{Theoretical perspectives}

National governments face competing demands on budgetary resources from political groups. Although some domestic constituencies may favor foreign aid either due to instrumental reasons or normative reasons (Ruttan 1996), resources spent on foreign aid come at the expense of satisfying domestic interests. And yet, developed countries have provided aid to developing countries for decades. What leads governments to invest political capital in justifying aid expenditures rather than allocating resources to domestic priorities? An influential school of thought argues that the motivation to support foreign aid can be traced to "the humanitarian and egalitarian principles of the donor countries, and...their implicit belief that only on the basis of a just international order in which all states had a chance to do well was peace and prosperity possible" (Lumsdaine 1993: 30; see also Pratt 1989; Stokke 1989). This line of research suggests that countries with higher commitments to domestic social spending, stronger leftist political parties and more popular support for international redistribution are considerably more generous foreign aid donors: the states with the most consistently generous aid records (the Nordic states and the Netherlands) are precisely those which have the strongest domestic social welfare programs (Lumsdaine 1993). Developing this argument further, Thérien and Noël (2000) argue that the cumulative power of the left shapes foreign aid choices. In this view, the strength of leftist parties influences aid levels in an indirect way, since leftist party power leads to increased foreign aid only by first leading to the creation a welfare state with more socialist attributes. In the same vein, these scholars argue that popular support for reducing global inequalities through the distribution of aid increases only once domestic inequalities have been mitigated (Noël and Thérien 2002). Thus, the humanitarian values that underpin a political environment where generous domestic welfare programs are possible also generate support for sending aid overseas.

There are grounds for doubting whether humanitarian values or welfare state regimes in and of themselves are determinants of levels of donor generosity. For one, research on the welfare state suggests that welfare regime type reflects the nature of power balances between contending forces in the domestic political economy (Esping-Anderson 1990) rather than an expression of altruism. Moreover, the welfare state has been viewed as a means of cushioning domestic groups from international market volatility and displays protectionist qualities (Myrdal 1960; Cameron 1978; Rodrik 1998). In addition, aid, like all other public expenditures, can compete with spending for domestic social programs in the budgetary process.

\footnotetext{
2 'Trade, not aid' has a long history in development discourse, notably in the United States, where the slogan figured prominently in the Eisenhower administration's aid program (Kaufman 1982). However, the emphasis on aid as a development instrument increased under the Kennedy administration as manifested in programs such as the Alliance for Aid under which Kennedy pledged \$20 billion in aid to Latin America.
} 
Although the above analyses focus on domestic-level determinants of donor generosity, some scholars have noted the importance of international normative factors such as a growth in internationalism in the aftermath of World War II and the increasing prominence of international organizations in world politics in explaining aid policies (Lumsdaine 1993; Finnemore 1996; Chabbott 1999; but see Botcheva and Martin 2001). Prior research has, however, ignored the potential influence of international economic linkages on aid choices and scholars have neglected the implications of the 'trade not aid' debate for aid budgets in particular. This is a significant omission given that donors and recipients alike are increasingly suggesting that the provision of market access to exports from developing countries is an essential prerequisite for promoting economic development. Uganda's Trade Minister, Edward Rugumayo, recently noted that "economic growth in Africa depends on donor funds and this is like building an economy on a pack of cards or shifting sand. Export trade should be the solid ground on which economies should be built." ${ }^{3}$ In his congressional testimony on the African Growth and Opportunity Act in 1997, Benjamin Kipkorir, the Kenyan Ambassador to the United States noted that: "Aid must be accompanied by specific economic policies...that allow free access for African products to the rest of the world. Africans have come to realize that trade not aid is the way to the future" (Kipkorir 1997).

Since the 1980s, developing countries' exports to OECD donor countries have increased substantially. Several factors have likely contributed to this trend, including reduced tariff and non-tariff barriers by virtue of GATT/WTO commitments, and World Bank and IMF policies that encourage export orientation in developing countries. Some OECD countries have taken specific steps to encourage trade with developing countries, as the United States' African Growth and Opportunity Act and the European Union's Everything But Arms initiative have recently illustrated (US House of Representatives 1999; EU 2004).

Although foreign aid comprises a small fraction of donor governments' budgets- the most generous donors allocate only around 1\% of GNP to aid-it can be a politically contentious issue. Opinion polls suggest that citizens (incorrectly) believe that their governments provide significant levels of aid to developing countries, often at the expense of domestic priorities. A recent poll indicated that $54 \%$ of US respondents believed that the United States was spending too much on foreign aid. ${ }^{4}$ In another poll, $47 \%$ of U.S. respondents wanted foreign aid levels to be reduced. ${ }^{5}$ Even in countries where there is majority support for international redistribution, support for aid may be lower when the public believes that more immediate domestic concerns have not been resolved (Noël and Thérien 2002). Policymakers are sensitive to demands from their bases of support, and while certain domestic constituencies may benefit directly from donor aid programs, development aid serves a foreign constituency unlikely to provide political support or resources to decision makers. Given that aid outlays can reduce the funds available to address domestic problems, politicians have incentives to pare down aid budgets, divert the resources to domestic constituents, and justify this budgetary reallocation by pointing to increased imports from developing countries. As Senator Claiborne Pell, Chair of the US Senate Foreign Relations Committee, noted while opening the hearings on the Enterprise for the Americas Initiative in September, 1990:

\footnotetext{
3 “Trade not Aid, Says Minister.” The New Vision. http://www.newvision.co.ug/D/8/220/362360. Published May 26, 2004.

4 Washington Post/Kaiser Family Foundation/Harvard University nationwide poll conducted by Princeton Survey Research Associates. June 13-23, 2002. http://www.pollingreport.com/defense.htm; 09/27/2004.

5 The Gallup Poll. May 18-21, 2000. http://www.pollingreport.com/defense.htm; 09/27/2004.
} 
We are currently in the process of budget negotiations requiring difficult choices as to how to reduce the deficit. It is clear that foreign aid increases for the region are not feasible. Appropriately, this initiative emphasizes trade, not aid, as the answer to economic recovery (US Senate 1990).

To justify reductions in aid budgets, politicians can suggest that economic development is more likely to follow from policies that encourage developing countries to participate in the world economy (Williamson 1993) than from resource transfers via aid, the efficacy of which has been widely debated (Dollar and Pritchett 1998). Indeed, aid critics have suggested that aid may actually counteract economic reforms by promoting the expansion of government or enabling developing country elites to resist economic and political reforms (Remmer 2004; Thorbecke 2000). Thus, an argument can be made that providing access to donor markets is a superior way of supporting economic development in developing countries (Morrissey 2000), and this can provide political cover for politicians wanting to trim aid budgets.

In sum, prior research has either concentrated on identifying a handful of domestic-level variables that correlate with foreign aid budgets or on international normative influences on domestic aid politics. It has ignored the core theoretical issue of instrument choice embedded in aid decisions and has neglected to situate foreign aid choices in the domestic and international economic context that frames resource allocation decisions. Our study provides an important corrective to the narrow treatment of the donor generosity question and is consistent with the now familiar call to better understand how international and domestic processes together influence foreign policies (Gourevitch 1978; Evans et al. 1993; Keohane and Milner 1996). As Frieden and Martin have noted: "The biggest challenge facing the field [IPE] is understanding the simultaneous interaction of domestic and international factors in determining foreign economic policies and international economic outcomes" (2001: 1). To identify the international and domestic determinants of foreign aid policies, we empirically test whether donor countries' foreign aid budgets are associated with imports from developing countries, controlling for explanations suggested by previous research and other alternative explanations.

\section{Data}

To study the relationship between developing country imports and foreign aid, we examine the foreign aid budgets of 19 OECD countries over a 20-year period: 1980-2000. These donors are Australia, Austria, Canada, Denmark, Finland, France, Germany, Ireland, Italy, Japan, the Netherlands, New Zealand, Norway, Portugal, Spain, Sweden, Switzerland, the United Kingdom, and the United States. We have excluded Belgium and Luxembourg from our sample because data on imports from the developing world was reported for the two countries combined for most of the period under study.

We focus on foreign aid distributed to Part I countries and territories on the aid recipient list prepared by the OECD's Development Assistance Committee (DAC). In 2000, this category included countries classified in the UN's Least Developed Country group (LLDCs), Low-Income Countries, Lower Middle-Income Countries, Upper Middle-Income Countries, and High-Income Countries. There is a broad range of average income among countries on the Part I list. As an example, for the year 2000 Low-Income Countries had per capita GNP equal to $\$ 760$ in 1998 while countries in the High-Income group had GNP per capita greater than $\$ 9360$ in 1998 . However, the great majority of countries on the 
list fall into the lower income categories: in 1998 there were 118 countries and territories classified in or below the Lower Middle-Income category compared to 23 countries and territories in the two higher income categories (OECD 2001). The Part I category distinguishes these developing countries from the Eastern European countries in transition and more advanced developing countries in the DAC's Part II category.

Our dependent variable, Donor Generosity, is operationalized as the ratio of Official Development Assistance to donor GNP. Official Development Assistance (ODA) refers to "grants or loans to countries and territories on Part I of the DAC list of aid recipients (developing countries) which are: undertaken by the official sector; with promotion of economic development and welfare as the main objective; at concessional financial terms" (OECD 2001). The ODA to GNP ratio is the standard yardstick used by the DAC to compare the aid performance of its members, and existing comparative research on donor generosity has also commonly adopted this measure. The key independent variable is the ratio of imports from developing countries to donor country GDP (Developing Country Imports). ${ }^{6}$ We empirically test whether the "Trade, not aid" argument has been put into practice by focusing on developing country imports rather than overall trade levels because import levels offer a direct indication of the extent of developing economies' penetration of donor markets. This measure fits with the central thrust of the "Trade, not Aid" argument which suggests that increases in a developing economy's exports will provide more development benefits than foreign aid can deliver.

It is important to note that the argument presented here does not address the question of how aid or trade flows are distributed geographically. We suggest that policymakers set overall aid levels without taking the specific circumstances of every recipient country into account. Our speculation is that decision makers equate rising import levels from developing countries with a diminished need for foreign assistance. Because increased imports from China may very well displace aid to Africa, ${ }^{7}$ the "Trade, not Aid" prescription may as a consequence spread benefits and costs asymmetrically across developing countries, perhaps even to the detriment of the poorer developing countries.

\section{International controls}

Our analysis controls for a slate of international and domestic factors (see Appendix 1 for descriptive statistics and Appendix 2 for data sources). Arguably, it is not the levels of imports from developing countries per se but the trade deficit with developing countries that triggers domestic opposition to aid, thereby creating pressures for politicians to pare down aid budgets. Trade surpluses with developing countries can be viewed as evidence that foreign aid is creating markets for donor country exports, while trade deficits can be

\footnotetext{
6 This measure comes from UNCTAD's Handbook of Statistics Online. The 'Developing Country Economies' listed by UNCTAD with limited exceptions overlap with the Part I Countries that the dependent variable measure covers. Several former-Soviet republics in Central Asia are not listed as 'Developing Country Economies' by UNCTAD although the OECD does list them as Part I aid recipients. However, most post-communist countries in Central and Eastern Europe, along with Russia and Ukraine, are excluded from both the ODA measure and the trade measure. There is one other category of exceptions: trade figures for high-income developing countries which were transferred to the DAC's Part II list in the late 1990s are listed as 'Developing Country Economies' by UNCTAD throughout the period covered.

7 In our view, policymakers are unlikely to examine increasing imports on a country-by-country basis from more than 100 developing countries and devise aid reductions accordingly. We speculate they tend to treat developing countries as a group in this regard. Our paper provides an empirical test for this speculation.
} 
portrayed as the export of jobs from donor countries to developing countries. As a result, trade deficits with developing countries are likely to be viewed negatively in donor countries and this can undermine political support for foreign aid. Hence, we include the ratio of trade balance with developing countries to donor GDP (Trade Balance) as a covariate.

Foreign direct investment from donor country firms in developing countries represents another way to transfer resources to developing countries. In addition to alleviating resource scarcity, foreign investors disseminate new technologies (Roemer 1993) and introduce new skills and managerial models, all of which can contribute to economic development (Rappaport 2000). Because foreign investment flows are associated with well-identified home countries, donor country politicians could well employ it as a reason to reduce aid levels. However, donor country multinational corporations might hope to benefit from an improved economic climate in developing countries and push their governments to maintain development assistance programs. While the direction of the relationship is not clear, foreign direct investment from donor country firms to developing countries could affect aid budgets, and we examine this potential effect by adopting foreign direct investment from the donor country to developing countries as a proportion of donor GDP as a control $(F D I){ }^{8}$

Foreign aid budgets could also be influenced by ideals of reducing global inequalities. Such norms are likely to flow through networks of non-governmental (Chabbott 1999; Boli and Thomas 1999) and inter-governmental organizations (Lumsdaine 1993; Finnemore 1996). While increasing national embeddedness in international networks would be expected to encourage donor generosity, these networks could also provide forums for the promotion of alternatives to foreign aid. If international forums elevate the trade-not-aid idea as an international development norm, for example, this could weaken support for foreign aid as a development instrument. To control for international normative influences via "World Society" networks (Meyer et al. 1997), we include two variables that reflect donors' membership in networks of intergovernmental organizations (IGO, Inter-Governmental Organizations) and international non-governmental organizations (INGO, NonGovernmental Organizations). Norms about appropriate levels of foreign aid giving are likely to flow more easily between contiguous countries than between non-contiguous countries. Neighbors are likely to have regular opportunities to exchange information and to observe one another. We therefore control for a neighborhood effect (Neighbor) via a spatial lag measured as the average Donor Generosity in neighboring countries in the previous year.

The end of the Cold War may very well have affected foreign aid budgets. During the Cold War, aid budgets were linked to the competition for allies in the rivalry between the Western bloc and the Soviet Union (Dunning 2004). With the end of the superpower confrontation, the tendency to base aid budgets on a desire to keep developing countries in the Western camp could have diminished. Therefore, we control for the changed international strategic context following the end of the cold war (Cold War). This is a dummy variable coded 1 for 1980-1990 and coded 0 for 1991-2000. The Cold War variable also allows us to control for other differences in the international context that might distinguish

\footnotetext{
${ }^{8}$ Portfolio flows can also be viewed as vehicles to transfer resources to developing countries. Unlike trade and foreign direct investment, portfolio flows are typically not associated with specific donor countries. Hence, we do not expect them to influence foreign aid decisions of donor countries. To empirically test our argument, we included portfolio flows in a prior model but did not find them significant or highly correlated with developing country imports. Their exclusion does not influence the significance or directionality of the variable of substantive interest.
} 
the 1980s from the 1990s. In particular, one could argue that global trade liberalization in the 1990s led to increased exports from developing countries to donor countries, suggesting that 'trade, not aid' dynamics pertain to the 1990s only.

\section{Domestic controls}

Our model also controls for several domestic level factors that prior research has identified as key drivers of foreign aid decisions. Lumsdaine (1993) suggests that the normative concerns that underlie support for domestic social welfare programs also promote generosity vis-à-vis the world's poor. Noël and Thérien (1995) explain variations in aid budgets in terms of variations in welfare regime type, suggesting that social democratic welfare states will give more foreign aid than welfare states of the liberal or conservative varieties. Because Noël and Thérien identify the number of socialist welfare state attributes as the main predictor of international generosity, they indicate that changes in national commitments to specific types of welfare programs over time could shape changes in patterns of overseas giving. However, because they rely on Esping-Andersen's measures of socialist, conservative, and liberal welfare state attributes for 1980 only, their conclusions rest on a static understanding of the welfare state. Although welfare state institutions and the policies associated with them are likely to be fairly stable over time (Pierson 1996), applying welfare state indicators from a single year to an analysis of foreign aid over a period of two decades is problematic, particularly since this focus suggests that aid levels, too, are unlikely to change much across time. ${ }^{9}$ By adopting social spending as an indicator of domestic welfare policies, it is possible to evaluate whether changing priorities with respect to domestic redistribution affect donor aid decisions. Social spending refers here to the 'public social expenditure' measure reported in the OECD's Social Expenditure Database (OECD 2004). ${ }^{10}$ This measure is defined as "the provision by public institutions of benefits to households and individuals in order to provide support during circumstances which adversely affect their welfare." This is a broad measure covering pensions, income support, unemployment benefits, housing benefits, public health expenditures, and other benefits. In short, we control for social spending as a proportion of donor GDP (Social Spending) because countries that favor domestic redistribution may also favor international redistribution via aid.

According to Thérien and Noël (2000), where leftist parties have captured political power over a longer period of time, social democratic welfare state ideas are likely to be more institutionalized, leading to higher levels of domestic social spending and donor generosity. Thus, our model controls for leftist political power through two variables: left seats in parliament as a percentage of seats held by all government parties (Left Cabinet) and cumulative left seats as a percentage of seats held by all government parties since 1946 (Cumulative Left). ${ }^{11}$ Leftist parties are not the only political actors that contributed to the development of the welfare state (Thérien and Noël 2000). Religious parties, too, have

\footnotetext{
9 We nevertheless checked for the impact of the original socialist welfare state dummy in our model. The variable was statistically insignificant and did not change the results presented below.

${ }^{10} \mathrm{http} / / / \mathrm{www}$.oecd.org/els/social/expenditure.

11 The source for these measures of leftist power is the Huber et al. Comparative Welfare States Database, which is the source for the data used in previous studies exploring partisan and welfare state influences on aid politics (Noël and Thérien 1995, 2002). We also examined our model by excluding all the cumulative partisanship measures and our substantive results remained unchanged. We decided to retain these measures because they offer a plausible hypothesis that is contrary to the 'trade, not aid' argument.
} 
historically promoted policies that favor social protection (van Kersbergen 1995), and the power of these parties over time might also influence levels of aid provision. Our model therefore includes two variables to reflect the potential influence of Christian Democratic parties on aid decisions: Christian Democratic seats as a percentage of seats held by government parties (Christian Cabinet) and cumulative Christian Democratic seats as a percentage of seats held by government parties since 1946 (Cumulative Christian Democrats). ${ }^{12}$

Foreign policy decisions may also be shaped by non-partisan features of the domestic political landscape. Scholars have highlighted the potential impact of gender on foreign policy attitudes and have associated greater gender equality with increased peacefulness in a state's foreign policy (Caprioli 2000). The gender gap in foreign policy attitudes extends beyond views toward conflict: Togeby (1994) argues that women have a stronger commitment to international solidarity than men and support more generous assistance to developing countries. Testing the link between levels of female representation in parliament and aid performance, Breuning (2001) finds that a stronger female presence in parliament increases giving. Hence, we control for the share of seats held by women in parliament (Women in Parliament). ${ }^{13}$

Although foreign aid comprises a small fraction of donor country budgets, aid provision may be more unpopular with decision makers when domestic economic conditions encourage budgetary belt tightening. High levels of unemployment, low per capita GDP, and poor economic growth may lead domestic actors to question the wisdom of diverting resources toward foreign aid. We therefore control for these features of the domestic economy (World Bank 2003). ${ }^{14}$

\section{Empirical model}

Our empirical model is a panel analysis that includes corrections for the statistical complications arising from such models. The model includes fixed effects dummy variables for each country because countries may differ in ways not fully captured by the independent variables (Green et al. 2001). An $F$-test and BIC test also suggested that fixed effects dummies should be included in the model.

As recommended by Beck and Katz (1995), we correct for panel heteroscedasticity by employing panel corrected standard errors (PCSE). Observations of the dependent variable may be spatially correlated if countries exert influence on each other through geographical proximity (O'Loughlin et al. 1998). We model this influence with the independent variable Neighbor, as discussed above. Within each country our observations over time are not independent: a realization of the dependent variable is conditional on the past value of the dependent variable. Because both a Lagrange multiplier test as well as Wooldridge's test for autocorrelation in panel data (2002: 176-177) indicate the presence of first order serial correlation, we include a lagged dependent variable (Beck and Katz 1995). All independent

\footnotetext{
12 These measures combine the values of Christian and Catholic parties of the right and center on the measures of parliamentary seats held by government parties and cumulative power from the Comparative Welfare States Dataset. They are consistent with the measures of Christian Democracy presented by Thérien and Noël (2000) and Huber et al. (1993).

13 The Fempar variable comes from the Huber et al. (2004) dataset.

14 In additional tests, we also examined our model by including budget deficits as a covariate. Because its inclusion did not affect our substantive results, we decided not to include it in the final model presented in this paper.
} 
variables are lagged by one year to account for delays in countries' response times (except for the variable Cold War).

Our data were not complete for all variables for all countries in our sample. King et al. (2001) suggest that dropping such countries from the sample induces biases and recommend that researchers impute missing data values. We applied the Amelia program to impute missing values in our data (Honaker et al. 2001). The results presented below are the adjusted averages from analyses of ten data sets with missing values imputed via Amelia. Our data were about $93 \%$ complete, with the international group membership variables having the most missing data (at 24\%) and the domestic and international economic indicators (partisanship, GDP, trade, etc.) being 100\% complete. Several countries had just a few cases of international group membership missing, whereas data incompleteness was more pronounced for Spain and Portugal (close to 30\%). However, we found no patterns to suggest that data were missing for specific years or that data incompleteness changed systematically over time for our data set. Our dependent variable, Donor Generosity, was $98.5 \%$ complete.

\section{Results}

Overall our analysis suggests that the 'trade, not aid' argument has translated into tangible policy outcomes. In other words, the increasing levels of imports from developing countries have displaced foreign aid that donor countries provide to them. We also find that social spending, which prior research has emphasized as the key driver of donor generosity, is not significant. Similarly, contrary to prior research we do not find international normative influences as transmitted via countries' membership in networks of international intern-governmental organizations or international non-governmental organizations as being significant. ${ }^{15}$ While we do not find support for other international variables, we do find evidence (i.e., statistical significance) that one domestic politics variable-unemployment levels - influences aid budgets. Table 1 presents the results of our statistical analyses of Donor Generosity of nineteen OECD countries from 1980 to 2000.

The main variable of interest, the ratio of imports from developing countries to donor GDP (Developing Country Imports), is statistically significant and negative (the coefficient is approximately -.81 ), implying that increased imports from developing countries are associated with diminished aid budgets. ${ }^{16}$ In effect, it appears that the 'trade, not aid' argument has translated into concrete policy choices. The confidence in this estimate is high. Holding other variables constant, a $1 \%$ increase in Developing Country Imports is associated with a $0.81 \%$ reduction in aid (Donor Generosity measured as ODA/GNP). In substantive terms, as a group, OECD countries in our sample provided about $\$ 50$ billion in foreign aid in 2000 . With a $1 \%$ increase in imports from developing countries, we would then expect that the aggregate foreign aid provided by rich countries to developing countries would decrease by more than a third of a billion dollars in 2001 .

\footnotetext{
15 An $F$-test indicates that both measures are not jointly significant.

${ }^{16}$ We do not believe that this negative relationship between imports and aid is the result of aid outflows reducing exports to donor countries. One main source of skepticism that reverse causality is at work here is that the size of trade flows far exceeds the volume of aid provided by the donor community (Fleck and Kilby 2006). In 2000, donor imports from developing countries amounted to $\$ 1.3$ trillion while aid totaled only around $\$ 50$ billion.
} 
Table 1 Effect of imports from developing countries to donor countries on donor aid budgets, 1980-2000

\begin{tabular}{lcc}
\hline Independent variables & Coefficient & SE \\
\hline (ODA/GNP) $t-1$ & $.697^{* *}$ & .051 \\
Developing country imports & $-.808^{*}$ & .443 \\
International factors & & \\
Trade balance & -.883 & .591 \\
FDI & -.392 & .834 \\
Inter-governmental organizations & .001 & .000 \\
Non-governmental organizations & -.000 & .000 \\
Cold War & -.015 & .015 \\
Neighbor & -.472 & 4.458 \\
Domestic factors & & .178 \\
Social spending & .002 & .001 \\
Cumulative left & -.001 & .011 \\
Left cabinet & -.008 & .001 \\
Cumulative Christian democrat & -.001 & .024 \\
Christian democrat cabinet & -.004 & .089 \\
Women in parliament & -.039 & .002 \\
Per capita income & -.003 & .161 \\
Unemployment & $-.538^{* *}$ & .166 \\
GDP growth & .160 & .057 \\
Constant & $.143^{* *}$ & \\
Fixed effects & Yes & \\
$R^{2}$ & .963 & \\
$N$ (19 countries, 20 years) & 380 & \\
\hline
\end{tabular}

Notes: Table entries are OLS estimates with panel corrected standard errors

Except for Cold War, all covariates are lagged by one year

One tailed t-test: $* p<.05, * * p<.01$

International controls - trade balance with developing countries (Trade Balance), foreign direct investment to developing countries $(F D I)$, membership in international InterGovernmental Organizations and Non-Governmental Organizations, and the international strategic context (Cold War) are not significant. Encouraging foreign direct investment to developing countries is also emphasized by aid critics, who argue that if the objective of aid is to alleviate capital scarcity in developing countries, then this goal can be just as well achieved by encouraging foreign direct investment. Our analysis indicates that international development assistance provided by donor countries is not influenced by foreign direct investment by the donor country's firms in developing countries. This non-finding underscores the ambiguous relationship between FDI flows and aid. While the expansion of FDI flows may reduce pressure on governments to transfer state resources directly to developing countries by providing developing states with an alternative source of foreign capital, firms might at the same time hope to benefit from infrastructure improvements in developing states and push donors to maintain development assistance programs.

Contrary to the claims made by prominent scholars such as Lumsdaine (1993) about the role of humanitarian ideas in shaping foreign aid policies, ideational globalization via 
international networks of inter-governmental and non-governmental organizations has not influenced donor generosity. There could be several explanations for this finding. First, our variables may not adequately capture ideational flows. Second, while these variables may be good proxies for ideational flows, they may transmit ideas in favor as well as against foreign aid. As a result, the effect of international norms on donor generosity-as captured in the proxy variables, Inter-governmental Organizations and Non-governmental Organizations - is not statistically significant.

Although foreign aid is an important instrument of foreign policy, our analysis suggests that the end of the Cold War has not influenced aid budgets in one clear direction. This is an interesting finding because foreign aid has often been viewed as an instrument to expand Western influence in developing countries. Arguably, our finding does not necessarily counter that claim. As Dunning (2004) demonstrates, the end of the Cold War likely marked a change in donor motivations for giving aid. Strategic concerns drove many aid decisions during the Cold War, but the end of the Cold War marked a turn toward promoting economic and political reform in recipient states. While these changes in donor motivation have likely influenced the geographical distribution of aid, our analysis indicates that the changed international security order has not affected the levels of aid distributed itself. This result also suggests that 'trade, not aid' dynamics have not been limited to the 1990 s. $^{17}$

Among the domestic predictors of donor generosity, Social Spending is the key domestic control. Prior research makes the argument that governments that care about domestic redistribution are also likely to support international redistribution. We do not find support for this argument. ${ }^{18}$ This is an important finding because it challenges the widely reported argument about the link between domestic redistribution and international redistribution. There are several possible explanations for the discrepancy between our results and earlier work on this issue. One central difference concerns the use of controls. Although Lumsdaine (1993) offers a wide-ranging analysis of foreign aid policies, his main conclusions are supported by basic correlations between the strength of private voluntary associations, social spending, and popular support for redistribution and aid expenditures, and thus do not evaluate how domestic and international economic factors in particular might influence a state's level of commitment to international redistribution. Noël and Thérien (1995) similarly restrict their exploration regarding the sources of donor generosity by focusing only on social spending, the strength of political parties, and the nature of welfare state institutions as predictors of aid patterns. These analyses identify important cross-national differences in aid commitments, but since the domestic values and social welfare hypotheses draw attention to relatively stable elements of the domestic political landscape, they are not wellsuited to explaining changes in levels of generosity over time or identifying the political tradeoffs between development assistance and other policies. However, even in the generous Nordic countries that provide the most immediate illustration of the social spending

\footnotetext{
17 We have also evaluated whether other changes in the international context have impacted aid decisions by adding year dummies for 1983 to reflect the debt crisis, 1993 to mark the establishment of the European Union, 1995 to indicate the devaluation of the CFA Franc, and 1998 to reflect the Asian Financial Crisis. With the exception of the 1998 year dummy, we find that donors have reduced aid in the wake of these shocks. These results suggest that the negative relationship we observe between trade flows and aid outlays is not a consequence of donors extending additional resources to developing countries to cope with these international shocks.

${ }^{18}$ Even when we exclude international factors from our model, social expenditures do not become statistically significant. We also examined whether collinearity among our explanatory variables is severe and found no evidence for inflated standard error around each parameter.
} 
and welfare state hypotheses, aid decisions are contestable and subject to change from year to year (Laatikainen 1996). Because the social spending and welfare state hypotheses can be regarded as the conventional wisdom in donor generosity research, we have attempted to replicate the studies that focus on these determinants of aid choices. We extend the model presented by Thérien and Noël (2000) to the broader time period our data covers and find that social spending actually has a negative relationship to aid outlays when country dummy variables are used in lieu of a marker of welfare state regime type. Partisan influences on aid giving are also not significant in this reduced model. ${ }^{19}$ The results of this replication attempt are presented in Appendix 3.

The domestic politics of foreign aid can be expected to be influenced by GDP Growth, GDP Per Capita and Unemployment levels. While GDP Growth and GDP Per Capita are not statistically significant, our results suggest that donors with a higher rate of unemployment in the previous year provide less foreign aid. A $1 \%$ increase in unemployment reduces foreign aid spending by .54 ceteris paribus. This result reflects the tradeoff between domestic and international spending priorities. As unemployment rates climb, governments face increasing pressure to prioritize domestic demands on their resources over international giving.

Among the partisanship variables, our model tested for the power of leftist parties and Christian Democratic parties. We also examined whether representation of women in parliament affects foreign aid decisions. None of these variables were significant. ${ }^{20}$ These results parallel the findings of Thérien and Noël (2000), who indicate that there is not a direct partisan effect on donor generosity. In contrast to Thérien and Noël, however, our results do not support the argument that the cumulative power of the left indirectly influences aid levels. Thérien and Noël argue that the long-term influence of leftist parties makes a mark on aid decisions because leftist power leads to the creation of a social democratic welfare state that promotes values favoring international redistribution.

Our finding that cumulative leftist power is not a predictor of donor generosity casts some doubt on an institutional explanation for foreign aid giving that centers attention on the nature of a state's redistributive system. Our results suggest that rather than simply reflecting the outcome of historical political compromises and the institutions they create, aid decisions are shaped by domestic and international economic considerations. In other words, the politics of foreign aid are not predetermined by the institutional innovations of the past. Governments take both the demands for domestic redistribution and the alternative options for promoting economic development into account in determining how much foreign assistance they should provide.

\section{Alternative specifications}

Our paper has examined whether imports from developing countries have a displacement effect on the foreign aid donors provide to them. An obvious question is: if the major

\footnotetext{
19 Thérien and Noël (2000) and the earlier studies on which they build test the social spending, welfare state, and partisan influence hypotheses using cross-sectional data from a very limited number of years. In Thérien and Noël (2000), for instance, the reported results draw on an analysis of data for two years only (1980 and 1991). We believe that it is problematic to evaluate the results for these isolated years, only, and have consequently used our data cover all of the years from 1980 to 2000 in attempting to replicate the findings of these studies.

${ }^{20}$ We also performed separate $F$-tests to test for joint significance of the two left power variables, the two Christian democratic power variables, and one female power variable. They were not significant either.
} 
benefactor from soaring exports to developed countries is China, is a "China Effect" driving our results? That is, could improved export performance in one corner of the developing world be encouraging more global reductions in aid? To examine this possibility, we simply excluded China from our analysis. As reported in Model 1 of Table 2, we find that the key independent variable, Developing Country Imports, retains statistical and substantive significance, and Social Spending, the key explanatory variable identified in prior research, is still not statistically significant.

One could also argue that while policy makers may not look at imports from over 100 developing countries and make aid decisions accordingly, they may look at countries

Table 2 Alternative measures and models

\begin{tabular}{|c|c|c|c|c|c|c|c|c|}
\hline \multirow[t]{3}{*}{ Independent variables } & \multirow{2}{*}{\multicolumn{2}{|c|}{$\frac{\text { Model } 1}{\text { No China }}$}} & \multirow{2}{*}{\multicolumn{2}{|c|}{$\frac{\text { Model } 2}{\text { No Africa }}$}} & \multirow{2}{*}{\multicolumn{2}{|c|}{$\frac{\text { Model } 3}{\text { No Latin America }}$}} & \multirow{2}{*}{\multicolumn{2}{|c|}{$\frac{\text { Model } 4}{\text { No Asia }}$}} \\
\hline & & & & & & & & \\
\hline & Coefficient & SE & Coefficient & SE & Coefficient & $\mathrm{SE}$ & Coefficient & $\mathrm{SE}$ \\
\hline$(\mathrm{ODA} / \mathrm{GNP})_{t-1}$ & $0.596 * *$ & 0.064 & $0.577 * *$ & 0.066 & $0.739 * *$ & 0.047 & $0.568 * *$ & 0.064 \\
\hline $\begin{array}{l}\text { Developing country } \\
\text { imports }\end{array}$ & $-0.821^{*}$ & 0.450 & $-1.045^{* *}$ & 0.437 & -0.636 & 0.439 & $-1.305^{*}$ & 0.658 \\
\hline \multicolumn{9}{|l|}{ International factors } \\
\hline Trade balance & -1.035 & 0.642 & $-1.336^{* *}$ & 0.553 & -0.692 & 0.538 & -1.225 & 0.856 \\
\hline FDI & -0.408 & 0.541 & 0.378 & 0.672 & -0.031 & 0.156 & -0.456 & 0.736 \\
\hline $\begin{array}{l}\text { Inter-governmental } \\
\text { organizations }\end{array}$ & 0.001 & 0.000 & 0.000 & 0.000 & 0.000 & 0.000 & 0.001 & 0.000 \\
\hline $\begin{array}{l}\text { Non-governmental } \\
\text { organizations }\end{array}$ & -0.000 & 0.000 & -0.000 & 0.000 & -0.000 & 0.000 & -0.000 & 0.000 \\
\hline Cold War & -0.013 & 0.015 & -0.010 & 0.010 & -0.009 & 0.013 & -0.005 & 0.013 \\
\hline Neighbor & 1.158 & 5.904 & 0.522 & 4.247 & 0.014 & 3.722 & 4.866 & 5.697 \\
\hline \multicolumn{9}{|l|}{ Domestic factors } \\
\hline Social spending & 0.028 & 0.177 & 0.082 & 0.132 & -0.026 & 0.153 & -0.056 & 0.159 \\
\hline Cumulative left & -0.001 & 0.002 & 0.000 & 0.001 & -0.000 & 0.001 & -0.001 & 0.002 \\
\hline Left cabinet & -0.006 & 0.013 & -0.012 & 0.010 & -0.006 & 0.009 & -0.002 & 0.012 \\
\hline $\begin{array}{l}\text { Cumulative Christian } \\
\text { democrat }\end{array}$ & -0.000 & 0.002 & -0.000 & 0.001 & 0.000 & 0.001 & 0.000 & 0.002 \\
\hline Christian democrat cabinet & -0.018 & 0.029 & -0.012 & 0.021 & -0.013 & 0.020 & -0.016 & 0.028 \\
\hline Women in parliament & -0.011 & 0.124 & -0.011 & 0.090 & -0.017 & 0.064 & 0.099 & 0.118 \\
\hline Per capita income & 0.000 & 0.000 & -0.000 & 0.000 & 0.000 & 0.000 & -0.000 & 0.000 \\
\hline Unemployment & $-0.561 * *$ & 0.176 & $-0.345^{* *}$ & 0.128 & $-0.527 * *$ & 0.138 & $-0.569 * *$ & 0.157 \\
\hline GDP growth & 0.081 & 0.180 & 0.035 & 0.135 & 0.188 & 0.134 & -0.011 & 0.166 \\
\hline Constant & $0.147 * *$ & 0.062 & $0.097 *$ & 0.044 & $0.103 * *$ & 0.048 & $0.134^{*}$ & 0.059 \\
\hline Fixed effects & \multicolumn{2}{|l|}{ Yes } & \multicolumn{2}{|l|}{ Yes } & \multicolumn{2}{|l|}{ Yes } & \multicolumn{2}{|l|}{ Yes } \\
\hline$R^{2}$ & \multicolumn{2}{|l|}{0.946} & \multicolumn{2}{|l|}{0.937} & \multicolumn{2}{|l|}{0.966} & \multicolumn{2}{|l|}{0.940} \\
\hline$N$ & \multicolumn{2}{|l|}{380} & \multicolumn{2}{|l|}{380} & \multicolumn{2}{|l|}{380} & \multicolumn{2}{|l|}{380} \\
\hline
\end{tabular}

Notes: Table entries are OLS estimates with panel corrected standard errors

Except for Cold War, all covariates are lagged by one year

One tailed $t$-test: $* p<.05, * * p<.01$ 
grouped by continents. In other words, does our argument hold when we focus on imports from and aid to Africa or Asia or Latin America? Similar to our approach to test the China Effect, we dropped each continent one by one from our dataset. As reported in Models 2, 3, and 4 of Table 2, we find that the key independent variable, Developing Country Imports, retains statistical and substantive significance of 5\% or below, while Social Spending is not statistically significant even when we focus on specific continents. Latin America is an exception: while Social Spending is not statistically significant, Developing Country Imports are significant but only at the $7 \%$ level. These results serve as additional evidence for our assertion that decision makers view developing countries as a group while deciding on budgetary allocations for development aid. While it is true that the strong economic performance of a handful of developing states can inordinately shape this perception, policy makers tend to view developing countries as a single group when making decisions about overall aid commitments.

Table 3 Alternative specification and estimation

\begin{tabular}{|c|c|c|}
\hline Independent variables & AR1 & Instrumental variables with robust $\mathrm{SE}$ \\
\hline$(\mathrm{ODA} / \mathrm{GNP})_{t-1}$ & & $.763 * *(.067)$ \\
\hline Developing country trade & $-1.576^{*}(.718)$ & $-1.077 *(.550)$ \\
\hline \multicolumn{3}{|l|}{ International factors } \\
\hline Trade balance & $-1.903 *(.873)$ & $-.848(.791)$ \\
\hline FDI & $-.259(.892)$ & $-1.275(1.531)$ \\
\hline Inter-governmental Organizations & $.001(.000)$ & $.001(.001)$ \\
\hline Non-governmental organizations & $-.000(.000)$ & $.000(.000)$ \\
\hline Cold War & $-.010(.020)$ & $-.045 *(.023)$ \\
\hline Neighbor & $6.797(5.872)$ & $-.925(6.426)$ \\
\hline \multicolumn{3}{|l|}{ Domestic factors } \\
\hline Social spending & $.092(.210)$ & $-2.078(1.304)$ \\
\hline Cumulative left & $-.001(.001)$ & $.000(.002)$ \\
\hline Left cabinet & $-.018(.015)$ & $-.012(.014)$ \\
\hline Cumulative Christian democrat & $-.001(.001)$ & $-.000(.002)$ \\
\hline Christian democrat cabinet & $.005(.032)$ & $.017(.038)$ \\
\hline Women in parliament & $-.083(.116)$ & $.112(.152)$ \\
\hline Per capita income & $-.004(.003)$ & $-.001(.002)$ \\
\hline Unemployment & $-.537 * *(.193)$ & $.249(.529)$ \\
\hline GDP growth & $-.295(.197)$ & $-.325(.379)$ \\
\hline Constant & $.279 * *(.081)$ & $.317 * *(.134)$ \\
\hline$\rho$ & .531 & \\
\hline Fixed effects & Yes & Yes \\
\hline$R^{2}$ & .849 & .942 \\
\hline$N$ (19 countries, 20 years $)$ & 380 & 380 \\
\hline
\end{tabular}

Notes: Table entries are OLS estimates. Panel corrected standard errors are included in the parenthesis Except for Cold War, all covariates are lagged by one year

One tailed $t$-test: $* p<.05, * * p<.01$

The instruments for the first stage were Age Dependency and Population 
We conducted further specification checks to examine the robustness of our findings to varying statistical estimating techniques. As reported in Table 3 below, we examined two different specifications of our model: estimation via instrumental variables and via an autoregressive term in place of a lagged dependent variable. We found that our key independent variable, Developing Country Imports, retains statistical and substantive significance while the key explanatory variable identified in prior research, namely Social Spending, is not statistically significant. These findings provide additional confidence in our empirical results.

Our analysis of the influence of imports from developing countries on donor generosity is complicated by the fact that Developing Country Imports can be expected to influence Donor Generosity directly as well as indirectly via its effect on Social Spending. ${ }^{21}$ To correct for such endogeneity, we employ a two-stage instrumental variable model. ${ }^{22}$ In the selection equation, we estimate levels of Social Spending using a slate of independent variables plus two instrumental variables (Population Size and Age Dependency Ratio) and then in the second stage, we estimate Donor Generosity with a slate of independent variables including the Social Spending variable predicted from the first model. Our substantive results hold up in this specification: Developing Country Imports is negative and statistically significant while social spending does not appear to be significant. Although emphasized in previous research, normative influences via the networks of International Non-governmental organizations and International Inter-governmental organizations are not associated with aid levels. However, we find that the variable Cold War becomes statistically significant but not in the theoretically expected direction.

Our second alternative specification addresses the issue of employing a lagged dependent variable (Achen 2000; Beck and Katz 2004; Plümper et al. 2005) in the model. Some have argued that the inclusion of a lagged dependent variable reduces the variance left for the explanatory variables (Achen 2000). Yet, since both a Lagrange multiplier test as well as Wooldridge's test for autocorrelation in panel data (2002: 176-177) indicate the presence of first order serial correlation, we need to take this condition into account. In the second specification of the model, we combine panel corrected standard errors with an autoregressive term (AR1) that replaces the lagged dependent variable. In this specification as well, Developing Country Imports are statistically significant and negative while Social Spending is not statistically significant. However, the variable Trade Balance gains statistical significance and in the expected direction. This suggests that trade deficits with the developing world are associated with lower aid budgets in donor countries in the following year. This supports our theoretical prediction that trade deficits undermine support for international distribution via foreign aid.

In order to address the importance of imports as determinants of aid outlays, we conducted an additional test inspired by cross-validation methods. We find that adding imports as a variable to the model improves our understanding of aid giving. We first ran a regression for both the full model and a model without the imports variable for a subset of

\footnotetext{
${ }^{21}$ This indirect effect owes to the prospect that governments will attempt to cushion their populations from the potentially negative consequences of increased exposure to international trade by increasing domestic social spending (Cameron 1978; Katzenstein 1985). The nature of domestic redistribution might then shape a state's propensity for international redistribution.

22 A Durbin Wu Hausmann test for endogeneity (Davidson and MacKinnon 1993: 236-242; Wooldridge 2002: chapter 8) suggested that endogeneity may exist for our data. To ensure that Social Spending was not significant due to endogeneity issues, we performed this specification check. The key to this estimation is finding the appropriate instruments. We opted for population size and age dependency ratios are instruments for Social Spending. Neither of the two variables is highly correlated with donor generosity.
} 
the data (the years 1983-2000) and then computed the predicted values of the two subset regressions for the excluded data (1981-1982). Finally, we compared the differences of predicted values and actual outcomes for the two regressions using the sum of squared residuals. Including the imports variable in the regression analysis improves the predictive power of the model by several percentage points. In short, imports have a substantive and theoretically important effect on aid giving.

In sum, while the relative strength of the coefficients varied somewhat under the alternative specifications, the key variable of interest, Developing Country Imports, retains a negative and statistically significant relationship with the dependent variable, Donor Generosity, across different specifications. Further, the key variable identified in prior research, Social Spending, is not statistically significant in any specification. In addition, the other key drivers of aid budgets identified in prior research, international normative influences, which we have sought to capture in terms of a country's embeddedness in networks of International Inter-Governmental and International Non-Governmental Organizations, are not significant either. Given the recent discussion in the literature on estimating Time Series Cross-Sectional (TSCS) data, ${ }^{23}$ it is greatly encouraging that our empirical results hold across different estimation techniques.

\section{Conclusions}

This paper has examined the issue of instrument choice faced by developed countries to support development in poor countries. Because developing countries face capital scarcity and capital is often viewed as a sine qua non for development, rich countries can promote economic development via resource transfers. Prior research has identified foreign aid as an instrument for redistributing resources internationally. It has not placed the issue of aid in the larger context of the politics of instrument choice. Drawing on the 'trade versus aid' debate, this paper argues that varying levels of donor generosity can only be understood when increased imports from developing countries to donor countries are taken into account.

Our analyses confirm that rising levels of OECD imports from developing countries are associated with reductions in OECD government's foreign aid allocations. Thus, key OECD policymakers, with an eye towards their domestic constituencies, are reducing aid budgets and justifying this by pointing to increased imports from developing countries. While prior research has emphasized the importance of social spending in influencing foreign aid budgets, our analysis does not support this argument. We also do not find support for the partisanship variables that previous research has tended to emphasize. However, we do find evidence that domestic economic conditions in the donor country, and unemployment levels in particular, influence foreign aid budgets. Thus, only some aspects of the domestic political context are important in shaping aid decisions.

The 'trade, not aid' debate has been around for nearly as long as the foreign aid regime itself, and has figured prominently in foreign aid discussions in the United States at least since the Eisenhower administration. However, the promotion of trade openness on the international development agenda in the past two decades has increased its

\footnotetext{
${ }^{23}$ See for example Franzese and Hays (2005) or the papers presented at the APSA (2005) panel "TimeSeries Cross-Section Data Analysis." We employed several other estimation techniques including the removal of the fixed effects and also followed Plümper et al.'s (2005) recommendations regarding the estimation of slowly changing or invariant variables and found that the relationship between trade and aid remains negative and statistically significant.
} 
prominence. Our paper suggests that the 'trade, not aid' argument has had a significant policy impact in donor countries: increased imports from developing countries have displaced foreign aid. This trend has several policy implications. If increased market access leads rich countries to reduce foreign aid, then developing country governments may have fewer options to explore alternative developmental paths. Moreover, citizens within developing countries may not benefit equally from the type of development that trade promotes, since benefits would likely be concentrated in the outwardly oriented sectors of the economy. Reduced aid may accentuate global inequalities, especially if certain developing countries do not have the resources or skills valued in global markets (Stiglitz 2002).Finally, reductions in foreign aid may also weaken rich countries' leverage to promote democracy and human rights in the developing world. While trade sanctions represent one alternative means of achieving this objective, research suggests that although sanctions may serve an important symbolic purpose, their efficacy in producing changes in state behavior is limited (Lindsay 1986).

As the WTO's Doha Ministerial Declaration demonstrates, the argument that international trade is an essential means of promoting economic growth and poverty alleviation in the developing world occupies a prominent place on the multilateral trade agenda. If international trade has become the key instrument to foster development ( $\$ 2200$ billion in OECD-developing country trade versus $\$ 50$ billion in aid in 2000), then international development scholars need to closely scrutinize the rules influencing the division of gains from trade, not only between the North and the South, but also within the South. Although the WTO is the key multilateral trade regime, a slew of regional and bilateral trade agreements are also affecting the volume and directionality of trade. Such trade agreements should be carefully examined not only in terms of gains and losses for the signatories, but also in terms of how they create trade for and divert trade from non-signatories (De Melo and Panagriya 1992). Because geography may privilege some developing countries regarding trade with OECD countries (Dunning 1981), the 'geographically challenged' countries may face difficult structural constraints in gaining access to international trading networks through no fault of their own. One way to address these structural disadvantages could be to include a 'side agreement' on foreign aid in regional and bilateral trade agreements. In sum, international trade and international development scholars need to closely examine this complex issue.

In addition to paying increased attention to the distribution of gains from trade in the developing world, this analysis suggests that it is essential that future research examine the way that geographical patterns of aid allocations have changed within the context of overall aid reductions. The developing countries that benefit from increased trade with the developed world and those that are hurt by aid cutbacks may not overlap. Thus strong export performance among other developing states may further reinforce the disadvantages facing the most aid dependent states by reducing the level of official assistance offered by donors.

Just as geography or the absence of efficient economic institutions limit the ability of some countries to reap the advantages of increased international trade, some states are at a fundamental economic disadvantage due to a lack of political control within their territory. The recent 'War on Terror' has drawn attention to failed states (Fukuyama 2004) and to how poverty facilitates the recruitment of terrorists (Posen 2001/2). Because failed states cannot guarantee property rights, they are unlikely to successfully participate in international economic exchanges. Trade as an instrument for development will not have traction for such countries, while foreign aid may still enable donor countries to support programs that counter poverty. An excessive reliance on trade as an instrument for economic 
development may thus have important implications for international security in addition to its consequences in the realm of international economics.

Acknowledgments Previous versions of this work were presented at Aston University in July, 2005 and at the 2005 Annual Meetings of the American Political Science Association and the Association for Public Policy Analysis and Management. The authors wish to thank Matt Potoski, John Ahlquist, Erica Johnson, Melissa A. Thomas, and Mike Ward as well as the anonymous reviewers for their useful advice.

\section{Appendices}

Appendix 1 Descriptive statistics of main variables ${ }^{\mathrm{a}}$

\begin{tabular}{lrrrr}
\hline Variable & \multicolumn{1}{c}{ Mean } & Std. Dev. & \multicolumn{1}{c}{ Min } & \multicolumn{1}{c}{ Max } \\
\hline ODA/GNP & 0.447 & 0.280 & -0.094 & 1.200 \\
Developing country imports & 0.037 & 0.018 & 0.014 & 0.139 \\
Trade balance & -0.002 & 0.019 & -0.089 & 0.037 \\
FDI & 0.003 & 0.005 & -0.009 & 0.046 \\
Inter-governmental organizations & 70.184 & 14.872 & 31.223 & 114.760 \\
Non-governmental organizations & 2078.871 & 626.558 & 170.536 & 4003.919 \\
Cold War & 0.500 & 0.500 & 0.000 & 1.000 \\
Neighbor & 0.004 & 0.002 & 0.000 & 0.010 \\
Social spending & 0.219 & 0.062 & 0.054 & 0.422 \\
Cumulative left & 13.312 & 11.709 & -35.965 & 44.860 \\
Left cabinet & 0.334 & 0.389 & -1.290 & 1.362 \\
Cumulative Christian democrat & 7.287 & 11.281 & -26.495 & 39.700 \\
Christian Democrat cabinet & 0.132 & 0.243 & -0.492 & 0.880 \\
Women in parliament & 0.163 & 0.114 & -0.138 & 0.427 \\
Per capita income & 17.682 & 5.813 & 5.960 & 35.130 \\
Unemployment & 0.079 & 0.044 & -0.024 & 0.239 \\
GDP growth & 0.027 & 0.022 & -0.063 & 0.111 \\
Age dependency & 0.506 & 0.045 & 0.436 & 0.699 \\
Population & 41.100 & 59.300 & 3.145 & 282.000 \\
\hline
\end{tabular}

a These statistics are based on ten imputed datasets with 380 cases

Appendix 2 Variable descriptions and sources

\begin{tabular}{|c|c|}
\hline Variable & Description and sources \\
\hline ODA/GNP & $\begin{array}{l}\text { Official Development Assistance as a Percentage of GNP; Development } \\
\text { Cooperation Report: Efforts and Policies of Members of the Development } \\
\text { Assistance Committee, various years. }\end{array}$ \\
\hline $\begin{array}{l}\text { Developing country } \\
\text { imports }\end{array}$ & $\begin{array}{l}\text { Volume of imports from developing countries in US dollars, divided by donor } \\
\text { GDP; UNCTAD Handbook of Statistics Online }\end{array}$ \\
\hline Trade balance & $\begin{array}{l}\text { Trade balance with the developing world as trade balance with developing } \\
\text { countries (exports to developing countries minus imports from developing } \\
\text { countries), divided by donor GDP; UNCTAD Handbook of Statistics Online }\end{array}$ \\
\hline FDI & $\begin{array}{l}\text { Direct investment in the developing world in US dollars, divided by donor GDP; } \\
\text { Development Cooperation Report: Efforts and Policies of Members of the } \\
\text { Development Assistance Committee, various years. }\end{array}$ \\
\hline $\begin{array}{l}\text { Inter-governmental } \\
\text { organizations }\end{array}$ & $\begin{array}{l}\text { Number of country memberships in international governmental organizations, } \\
\text { Yearbook of International Organizations, various years. }\end{array}$ \\
\hline
\end{tabular}


Appendix 2 continued

\begin{tabular}{|c|c|}
\hline Variable & Description and sources \\
\hline $\begin{array}{l}\text { Non-governmental } \\
\text { organizations }\end{array}$ & $\begin{array}{l}\text { Number of memberships in international nongovernmental organizations, } \\
\text { Yearbook of International Organizations, various years. }\end{array}$ \\
\hline Cold War & $\begin{array}{l}\text { Dummy variable coded } 1 \text { for years between } 1980 \text { and } 1990 \text { and } 0 \text { for the period } \\
\text { 1991-2000. }\end{array}$ \\
\hline Neighbor & $\begin{array}{l}\text { Variable calculated based on the average of development assistance allocations } \\
\text { (ODA as a percentage of GNP) in countries neighboring the donor country in } \\
\text { the previous year }\end{array}$ \\
\hline Social spending & Public Social Expenditure as percentage of GDP; www.sourceoecd.org \\
\hline Cumulative left & $\begin{array}{l}\text { Cumulative left Cabinet score from } 1946 \text { to the year of observation; Comparative } \\
\text { Welfare States Dataset }\end{array}$ \\
\hline Left cabinet & $\begin{array}{l}\text { Left seats as a percentage of seats held by all government parties; Comparative } \\
\text { Welfare States Dataset }\end{array}$ \\
\hline $\begin{array}{l}\text { Cumulative Christian } \\
\text { democrat }\end{array}$ & $\begin{array}{l}\text { Cumulative Christian Democratic Cabinet score from } 1946 \text { to year of } \\
\text { observation; Comparative Welfare States Dataset }\end{array}$ \\
\hline $\begin{array}{l}\text { Christian democrat } \\
\text { cabinet }\end{array}$ & $\begin{array}{l}\text { Christian Democratic seats as percentage of seats held by all government parties } \\
\text { (composite of religious party measures including Christian and Catholic parties } \\
\text { of the center and the right); Comparative Welfare States Dataset }\end{array}$ \\
\hline Women in parliament & $\begin{array}{l}\text { Seats held by women as a percentage of total seats in parliament; Comparative } \\
\text { Welfare States Dataset }\end{array}$ \\
\hline Per capita income & $\begin{array}{l}\text { GDP per capita, purchasing power parities (current international dollars, in } \\
\text { thousands); World Development Indicators Online }\end{array}$ \\
\hline Unemployment & Unemployment Rate; World Development Indicators Online \\
\hline GDP growth & Annual GDP growth rate; World Development Indicators Online \\
\hline Age dependency & $\begin{array}{l}\text { Age-Dependency Ratio (Dependent population under } 15 \text { and over } 65 \text { divided by } \\
\text { the working-age population); World Development Indicators Online }\end{array}$ \\
\hline Population & Population in millions; World Development Indicators Online \\
\hline
\end{tabular}

Appendix 3 Replication of existing models explaining donor generosity

\begin{tabular}{lrr}
\hline Independent Variables & Coefficient & SE \\
\hline (ODA/GNP $)_{t-1}$ & 0.738 & 0.050 \\
Left cabinet & -0.002 & 0.010 \\
Christian democrat cabinet & 0.014 & 0.024 \\
Cumulative left & -0.001 & 0.001 \\
Cumulative Christian democrat & -0.001 & 0.001 \\
Social spending & -0.347 & 0.131 \\
Constant & 0.088 & 0.022 \\
Fixed effects & Yes & .912 \\
$R^{2}$ & 380 & SE \\
$N(19$ countries, 20 years $)$ & Coefficient & 0.024 \\
\hline Independent variables & 0.923 & 0.010 \\
\hline (ODA/GNP) $)_{-1}$ & 0.003 & 0.020 \\
Left cabinet & 0.003 & \\
Christian democrat cabinet & & \\
\hline
\end{tabular}


Appendix 3 continued

\begin{tabular}{lcc}
\hline Independent Variables & Coefficient & SE \\
\hline Cumulative left & 0.000 & 0.000 \\
Cumulative Christian democrat & 0.000 & 0.000 \\
Social spending & -0.117 & 0.100 \\
Welfare state dummy & 0.049 & 0.016 \\
Constant & 0.039 & 0.019 \\
Fixed effects & Yes & \\
$R^{2}$ & .921 & \\
\hline
\end{tabular}

\section{References}

Achen, C. (2000). Why lagged dependent variables can suppress the explanatory power of other independent variables. Presented at the Annual Meeting of the Society for Political Methodology, UCLA.

Beck, N., \& Katz, J. N. (1995). 'What to do (and not to do) with time-series cross-section data. American Political Science Review, 89, 634-647.

Beck, N., \& Katz, J. N. (2004). Time-series cross-section issues: Dynamics. Draft Manuscript. Accessed at: http://polmeth.wustl.edu/retrieve.php?id = 36; 09/01/2004.

Boli, J., \& Thomas, G. M. (Eds.) (1999). Constructing world culture: International non-governmental organizations since 1875. Stanford, CA: Stanford University Press.

Botcheva, L., \& Martin, L. L. (2001). Institutional effects on state behavior: Convergence and divergence. International Studies Quarterly, 45, 1-26.

Breuning, M. (2001). Women's representation and development assistance: A cross-national study. Women and Politics, 23, 35-54.

Cameron, D. R. (1978). The expansion of the public economy: A comparative analysis. American Political Science Review, 72, 1243-1261.

Caprioli, M. (2000). Gendered conflict. Journal of Peace Research, 37, 51-68.

Chabbott, C. (1999). Development INGOs. In J. Boli \& G. M. Thomas (Eds.), Constructing world culture: International nongovernmental organizations since 1875 (pp. 222-248). Stanford: Stanford University Press.

Collier, P., \& Dollar, D. (2004). Development effectiveness: What have we learnt? The Economic Journal, 114, F244-F271.

Davidson, R., \& MacKinnon, J. G. (1993). Estimation and inference in econometrics. New York: Oxford University Press.

De Melo, J., \& Panagariya, A. (Eds.) (1992). New regionalism in trade policy. Washington, DC: The World Bank.

Dollar, D., \& Pritchett, L. (1998). Assessing aid: What works, what doesn't, and why. New York: Oxford University Press.

Dunning, J. (1981). International production and the multinational enterprise. Boston: Allen and Unwin.

Dunning, T. (2004). 'Conditioning the effects of aid: Cold war politics, donor credibility, and democracy in Africa. International Organization, 58, 409-423.

Esping-Andersen, G. (1990). The three worlds of welfare capitalism. Princeton: Princeton University Press.

European Union. (2004). FAQs. Accessed on September 19, 2004 at: http://europa.eu.int/comm/trade/ gentools/faqs_en.htm.

Evans, P. B., Jacobson, H. K., \& Putnam, R. D. (Eds.) (1993). Double-edged diplomacy: International bargaining and domestic politics. Berkeley: University of California Press.

Federal News Service. (1990). Remarks of President George Bush at Introduction of the Legislation 'Enterprise for the Americas Act of 1990'. (September 14).

Finnemore, M. (1996). National interests in international society. Ithaca: Cornell University Press.

Fleck, R. K., \& Kilby, C. (2006). How do political changes influence US bilateral aid allocations? Evidence from panel data. Review of Development Economics, 10, 210-223.

Franzese, R., \& Hays, J. (2005). Spatial econometric models for political science. University of Michigan: Book Manuscript. 
Frieden, J., \& Martin, L. L. (2001). International political economy: The state of the sub-discipline. Working Paper. Harvard University.

Fukuyama, F. (2004). The imperatives of state building. Journal of Democracy, 5, 17-31.

Gourevitch, P. (1978). The second-image reversed. International Organization, 32, 881-912.

Green, D. P., Kim, S. Y., \& Yoon, D. H. (2001). Dirty pool. International Organization, 55, 441-468.

Honaker, J., Joseph, A., King, G., Scheve, K., \& Singh, N. (2001). Amelia: A program for missing data (Windows version). Cambridge, MA: Harvard University. Accessed at: http://GKing.Harvard.edu/.

Huber, E., Ragin, C., \& Stephens, J. D. (1993). Social democracy, Christian democracy, constitutional structure, and the welfare state. American Journal of Sociology, 99, 711-749.

Huber, E., Ragin, C., Stephens, J. D., Brady, D., \& Beckfield, J. (2004). Comparative welfare states data set. Northwestern University, University of North Carolina, Duke University and Indiana University.

Jones, B. D., Baumgartner, F. R., \& True, J. L. (1998). Policy punctuations: US budget authority, 19471995. Journal of Politics, 60, 1-33.

Katzenstein, P. J. (1985). Small states in world markets: Industrial policy in Europe. Ithaca: Cornell University Press.

Kaufman, B. I. (1982). Trade and aid: Eisenhower's foreign economic policy, 1953-1961. Baltimore: Johns Hopkins University Press.

Keohane, R. O., \& Milner, H. V. (Eds.) (1996). Internationalization and domestic politics. Cambridge: Cambridge University Press.

King, G., Honaker, J., Joseph, A., \& Scheve, K. (2001). Analyzing incomplete political science data: An alternative algorithm for multiple impuation. American Political Science Review, 95, 49-69.

Kipkorir, B. (1997). Testimony before the trade sub-committee of the house ways and means committee. Hearing on the African Growth and Opportunity End of Dependency Act of 1996. (April 29).

Laatikainen, K. V. (1996). The disillusionment of Nordic aid. In S. W. Hook (Ed.), Foreign aid toward the new millennium (pp. 109-124). Boulder: Lynne Rienner Publishers Inc.

Lindsay, J. M. (1986). Trade sanctions as policy instruments: A reexamination. International Studies Quarterly, 30, 153-173.

Lumsdaine, D. H. (1993). Moral vision in international politics: The foreign aid regime 1949-1989. Princeton: Princeton University Press.

Meyer, J. W., Boli, J., Thomas, G. M., \& Ramirez, F. O. (1997). World society and the nation-state. American Journal of Sociology, 103, 144-181.

Morrissey, O. (2000). Foreign aid in the emerging global trade environment. In F. Tarp (Ed.), Foreign aid and development: Lessons learnt and directions for the future (pp. 375-399). London: Routledge.

Myrdal, G. (1960). Beyond the welfare state: Economic planning and its international implications. New Haven: Yale University Press.

Noël, A., \& Thérien, J. P. (2002). Public opinion and global justice. Comparative Political Studies, 35, 631656.

Noël, A., \& Thérien, J. P. (1995). From domestic to international justice: The welfare state and foreign aid. International Organization, 49, 523-553.

O’Loughlin, J., Ward, M. D., Lofdahl, C. L., Cohen, J. S., Brown, D. S., Reilly, D., Gleditsch, K. S., \& Shin, M. (1998). The diffusion of democracy, 1946-1994. Annals of the Association of American Geographers, $88,545-574$.

Organization for Economic Cooperation and Development. (various years). Development Cooperation Report: Efforts and Policies of Members of the Development Assistance Committee. Paris: OECD.

Organization for Economic Cooperation and Development. (2004). 'Source OECD,' Social Expenditure Database. Accessed at: www.sourceoecd.org.

Pierson, P. (1996). The new politics of the welfare state. World Politics, 48, 143-179.

Plümper, T., Troeger, V. E., \& Manow, P. (2005). Panel data analysis in comparative politics: Linking methods and theory. European Journal of Political Research, 44, 327-352.

Posen, B. R. (2001). The struggle again terrorism: Grand strategy, Strategy, and Tactics', International Security, 26, 39-55.

Pratt, C. (Ed.) (1989). Internationalism under strain: The north-south policies of Canada, the Netherlands, Norway, and Sweden. Toronto: University of Toronto Press.

Rappaport, J. (2000). How does openness to growth promote growth? Kansas City: Federal Reserve Bank of Kansas City.

Remmer, K. L. (2004). Does foreign aid promote the expansion of government? American Journal of Political Science, 48, 77-92.

Rodrik, D. (1998). Why do more open economies have bigger governments? The Journal of Political Economy, 106, 997-1032. 
Roemer, P. M. (1993). Idea gap and object gap in economic development. Journal of Monetary Economics, $32,531-555$.

Ruttan, V. (1996). United States development assistance policy: The domestic politics of foreign economic aid. Baltimore: Johns Hopkins University Press.

Stiglitz, J. E. (2002). Globalization and its discontents. New York: WW Norton.

Stokke, O. (Ed.) (1989). Western middle powers and global poverty: The determinants of aid policies of Canada, Denmark, the Netherlands, Norway, and Sweden. Uppsala: Scandinavian Institute of African Studies.

Thérien, J. P., \& Noël, A. (2000). Political parties and foreign aid. American Political Science Review, 94, $151-162$.

Thorbecke, E. (2000). The evolution of the development doctrine and the role of foreign aid, 1950-2000. In F. Tarp (Ed.), Foreign aid and development: Lessons learnt and directions for the future (pp. 17-47). London: Routledge.

Togeby, L. (1994). The gender gap in foreign policy attitudes. Journal of Peace Research, 31, 375-392.

UNCTAD. (2004). Handbook of statistics online. Accessed at: http://www.unctad.org.

Union of International Associations. (various years). Yearbook of international organizations. Munich: K.G. Saur Verlag.

United States House of Representatives Ways, Means Committee. (1999). African Growth and Opportunity Act: Report to Accompany H.R. 434. Washington, DC: GPO. June 17.

United States Senate. (1990). Hearing before the committee on foreign relations: Enterprise for the Americas Initiative, S. 3064. Washington, DC: GPO. September 27.

Van Kersbergen, K. (1995). Social capitalism: A study of Christian democracy and the welfare state. London: Routledge.

Wildavsky, A. (1992). The new politics of the budgetary process. New York: Harper Collins.

Williamson, J. (1993). Democracy and the 'Washington Consensus'. World Development, 21, 1329-1336.

Wooldridge, J. M. (2002). Econometric analysis of cross section and panel data. Cambridge: MIT Press.

World Bank. (2003). World development indicators online. Accessed at: http://devdata.worldbank.org/dataonline. 